\title{
The interplay between product and retail service meaning
}

\author{
Federico Artusi and Emilio Bellini \\ Department of Management, Economics and Industrial Engineering, \\ Politecnico di Milano, Milan, Italy
}

\begin{abstract}
Purpose - The innovation of meaning paradigm is a strategy to radically innovate product and service meanings. While researchers have focussed on the role of product and retail space meanings as interlinked in the pursuit of innovation, no investigation has been directed towards understanding when the two meanings differ. This research explores how companies can manage two different meanings offered through their retail services and the products sold.

Design/methodology/approach - Due to the highly intangible and subjective nature of meaning, as well as the exploratory aim of the research, a case study approach has been adopted. In particular, the research compares two case studies of similar companies in the beauty industry. Data were triangulated across three different sources: a panel of experts, ethnographic research in the two companies' stores and extensive academic and practitioner publications.

Findings - Findings suggest that innovating the service meaning can be a viable strategy to differentiate a retail offering the product meaning which is no longer perceived as different with respect to competitors.

Originality/value - The study applies the innovation of meaning concept to retail services, distinguishing the meaning given to the store from that given to products, thereby offering managers a strategy to innovate a suffering retail format.
\end{abstract}

Keywords Innovation of meaning, Customer experience, Retail innovation, Product innovation, Beauty retailing

Paper type Research paper

\section{Introduction}

The retail landscape has been shaken by major forces in recent years. The advent and development of online-based retailers introduced strong competition that challenges the role of physical stores (Childers et al., 2001), providing more utilitarian benefits and raising the expectations for the shopping into the physical channel (Loupiac and Goudey, 2020). Recent developments in the field have even eliminated the boundaries between the physical and the digital, with the concept of omnichannel retailing gaining fundamental importance in the field (Beck and Rygl, 2015; Verhoef et al., 2015).

Competition has changed in two main directions: on one side, the race to provide customers with smooth and effortless access to purchasing products, mainly through the digitalization of stores (Hagberg et al., 2016); on the other side, the increased focus on the customer experience (Meyer and Schwager, 2007; Verhoef et al., 2009) to create relevant and positive memories that can foster word of mouth and loyalty (Söderlund, 1998; Choi and Choi, 2014). Studies have focussed on retail innovation as a secondary lever to convey product innovation by linking the two dimensions in a seamless and integrated description of the brand offering. However, companies such as Adidas with the Runbase store or Starbucks with their new Roasteries show that innovation in the retail experience can be pursued separately from product innovation, enhancing the value of the store visit compared to product distribution. This is extremely

(C) Federico Artusi and Emilio Bellini. Published by Emerald Publishing Limited. This article is published under the Creative Commons Attribution (CC BY 4.0) licence. Anyone may reproduce, distribute, translate and create derivative works of this article (for both commercial and non-commercial purposes), subject to full attribution to the original publication and authors. The full terms of this licence may be seen at http://creativecommons.org/licences/by/4.0/legalcode

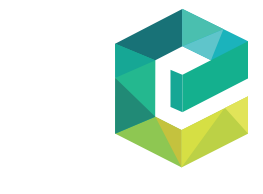

International Journal of Retail \& Distribution Management Vol. 49 No. 1,2021 Emerald Publishing $105-120$ 0959-0552 DOI 10.1108/IJRDM-12-2019-0395 
IJRDM

49,1 relevant for product-oriented companies that directly operate stores. The tendency of leveraging proprietary retail services has grown over the last years, especially in relation to enabling customer intimacy and controlling experience innovation efforts (Chiang et al., 2003).

Despite their historical focus on products, these companies are starting to pursue the innovation of their retail services as separate from the evolution of products. Taking the example of IKEA, while the starting point of product innovation followed what it calls "democratic design", the retail experience has evolved over the years from smart access to democratic products, to "do it yourself" service, to family destination stores, to temporary stores in large town centres (Rosner and Bean, 2009; Edvardsson et al., 2006). The innovation of meaning (IOM) framework (Verganti, 2009, 2017) enables understanding different dimensions of product and service innovation, comparing the "how" of the new solution with the "why" of the new meaning envisioned and designed by product and/or service companies. Thus, giving a new meaning or "reason why" (Verganti, 2017) to access the retail service may be an effective strategy to generate traffic and increase product sales, even when the reason for using the product remains unchanged. However, no prior studies have examined in an integrated way the two levels of product meaning and retail service meaning innovation, which is a crucial challenge for companies that directly operate a proprietary chain and need to sustain their product advantage (Huang and Huddlestone, 2009) in the current hypercompetitive, landscape.

This research aims at investigating the dichotomy between product innovation and retail service innovation to analyse the strategic option that brands have in innovating their stores. Thus, the research question is:

(1) How do companies manage the relationship between product and retail service meaning?

To perform the investigation, two main steps were performed. At first, the analysis of the literature allowed the researchers to draw the state of the art in the relationship between product and service IOM. Based on that, a gap in the available innovation strategies has been identified in the innovation of a service meaning as separate from the innovation of the products meaning. To investigate such a gap, a paired comparison method has been adopted, analysing two comparable cases: Lush and The Body Shop. These retail companies aim at providing the same product meaning to customers, sustainable consumption. However, the retail services are shaped in very different ways and communicate two different meanings. This study brings the evidence that pursuing the new meaning in retail service innovation as separate from product innovation can be a viable strategy to sustain or achieve competitive advantage.

The remainder of the paper is structured as follows. First, the review of the literature is presented alongside with a conceptual framework for the product and service IOM relationship. Thereafter, the methodology and the two cases are presented, along with a discussion regarding the way they have pursued their innovation strategies. Finally, conclusions and implications for both theory and practice are provided.

\section{Theoretical background}

The theoretical background of the research is grounded in studies on the potential impact of the IOM framework (Verganti, 2017) on the development of a radically new product or service. The literature review is organized into two sections. The first part analyses and discuss the main contributions related to radical product innovation and thereafter innovation in the retail service domain. The two literature streams are then synthesized in the light of the innovation of meaning and compared to provide a theoretical perspective to guide the empirical exploration.

\section{Radical product innovation}

The impact of technology innovations on the competitiveness of firms is widely explored in the strategy and innovation literature. Up to the 1990s, classic studies on corporate planning 
followed the structure-conduct-performance paradigm (Porter, 1996), considering the product and technology innovation approach as a second-order functional strategy supporting the firstorder competitive strategy (i.e. technology development for unique product features sustaining the differentiation advantage vs technology development for process innovation sustaining the cost advantage). In the 1990s and 2000s, strategic management studies were dominated by the resource-, knowledge- and dynamic-capabilities-based views (Hamel and Prahalad, 1992; Teece et al., 1997) that assume technological capabilities as the root of competitiveness, sources of new products and the foundation of strategies.

The product innovation literature followed a parallel, sometimes overlapping path, and it usually focusses on understanding and managing the evolutionary and cyclical nature of technological competition (Abernathy and Clark, 1985; Byun et al., 2018). Many scholars offered explanations for the outcomes of the standards wars and the emergence of winnertakes-all markets (Argyres et al., 2015). The technological innovation has been then linked to the product and the value created by the innovation and the share of this value that the innovator could appropriate. In recent years, product innovation has been interlinked with the business model and service innovation (Visnjic et al., 2016), to understand the synergies in impacting performances. Along with that, scholars gave increasing importance to the digital (Lyytinen et al., 2016) and design (Baxter, 2018) dimension of innovation.

The IOM framework has its roots in the cross-fertilization of design management and technology management (Utterback et al., 2006; Eisenman, 2013) and starts from the designdriven innovation model, which considers design the right approach to give sense to products (Krippendorff, 2008; Verganti, 2009). By following a process of interpretation of the society (Verganti, 2017), companies may give new meaning to their offering. The new meaning, which is usually defined internally, by individual or pairs of visionary leaders (Bellis and Verganti, 2019), defines the strategy upon which products are developed (Battistella et al., 2012) The role of the designer is that of facilitating people's interpretation of a product (Jahnke, 2012), by embedding signs in it (Sanasi et al., 2019).

The overlap between technology- and design-driven innovations has attracted other reflections (Trabucchi et al., 2017; Magistretti et al., 2020a), shaping the research stream related to the technology epiphanies that Verganti (2009) defined as a type of innovation strategy that allows combining technological breakthroughs with the radical innovation of product meaning, revealing the hidden value of new or existing technologies. In the definitive formulation of the IOM framework, Verganti (2017) explicitly conceptualized two different types of innovation:

(1) Innovation of meaning, namely a novel vision proposing a new reason to achieve the purpose, why people do things, why they buy and use the output delivered by innovative firms (why a product is used and loved).

(2) Innovation of solution, namely a new combination of products, services, brands, business models that people may use to achieve the purpose: how they do things, how they buy and use the output delivered by innovative firms (how the product works).

As Verganti (2017, p. 72) pointed out, "the difference with (existing) frameworks is not only terminological (meaning vs. value proposition) [...] whereas the frameworks above propose canvases in the realm of strategy, here (in the IOM) we dig deeper and move into implementation [...] to illustrate the process used to create new meaning".

\section{Radical service innovation}

As in the case of product and process innovation, service innovation allows firms to increase the quality or efficiency of the services provided, potentially gaining a competitive

Product and retail service meaning

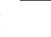


IJRDM

49,1 advantage. For this reason, service innovation has traditionally been described as purely incremental (Toivonen and Tuominen, 2009). In addition to that, and differently from products, services are intangible, heterogeneous, inseparable and perishable (Lovelock and Gummesson, 2004), which in turn increases the difficulty in investigating their innovativeness.

As for products, the technological dimension of innovation has continued to develop over the years, a central theme around which the debate is ongoing (Pantano et al., 2018; Magistretti et al., 2020b). The latest technological evolution in retail services lies in the concept of omnichannel retail (Beck and Rygl, 2015; Verhoef et al., 2015). Omnichannel strategies leverage the use of technologies in terms of digital touchpoints and channels as a way of aligning different customer preferences during the purchasing process (Bell et al., 2017). Through the omnichannel reconfiguration (Jocevski et al., 2019), retailers can keep pace with online-based players by both increasing their purchasing process efficiency and supporting the customer experience alongside the preferred use of channels (Pantano and Viassone, 2015; Hall and Towers, 2017).

In addition to the technology-push view, a more society-oriented perspective has developed over the years. Roth and Klein (1993) were among the first to conceptualize retail evolution as an adaptation to major evolving socio-cultural trends. In this way, retailers could innovate by understanding the values that emerge in society, thus tailoring the experience they offer. The customer experience, in turn, has recently garnered the interest of practitioners and scholars (Verhoef et al., 2009), considered a promising way to gain and nurture competitive advantage (Kranzbühler et al., 2018). Much research has been directed at providing a definition of the concept of the experience itself. Pine and Gilmore (1998) conceptualized experience as a construct that is managed and created by the company, using "service as the stage and goods as props to engage individual customers in a way that creates a memorable event" (p. 4). This view was still rooted in the offering itself, defining customer experience based on what people can benefit from. Schmitt (1999, p. 57) made a step further: experiences replace functional value by adding dimensions typical of "sensory, emotional, cognitive, behavioural and relational values".

In the service context, the innovation of meaning framework is related to the design of the more hedonic dimension of consumption (Verganti, 2017). Building on the concept of design as a meaning-making activity (Krippendorff, 2008), the innovation of meaning provides a frame to explore different ways in which customers may give meaning to a category of services, innovating the context of service usage in light of the changing socio-cultural institutions (Takeyama et al., 2016).

Thus, experience may function as the "what", the material manifestation of meaning as the "why" (Battistella et al., 2012). In fact, meaning is constructed in the user experience (Knudsen and Haase, 2019), which is the in-store reflection of the company's meaning strategy (Sanasi et al., 2019). Providing a new sense of why may be the starting point of the broader redesign of the service and the related experience, nurturing the radical innovation process (Artusi and Bellini, 2020). Previous studies have acknowledged the fact that the innovation of meaning process can be directed towards changing the purpose of the store, usually from a place where to purchase products to a place where to live experiences (Artusi et al., 2020). Perhaps, the more frequent example of repurposing of stores can be seen in the growing trend of bookstores that try to transform into "third places" by the addition of bars and restaurants (Laing and Royle, 2013). The following chapters examine the product and service innovation of meaning in their potential synergic application.

\section{Conceptual framework}

Assuming an innovation of meaning perspective, this article identifies two dimensions: on the vertical axis, the company defines the degree of novelty of the product meaning innovation 
(incremental or radical); on the horizontal axis, the company defines the novelty degree of the retail service meaning innovation (incremental or radical). In this way, the dichotomy between product and retail service innovation can be examined based on the four potential innovation strategies described.

Figure 1 distinguishes between three different innovation of meaning strategies (in addition to the incremental strategy of refining the meaning), based on what they aim to bring to the end customer:

(1) Synergic innovation of meaning: companies innovating both the product and how they sell it implies full and proper innovation of meaning (Verganti, 2017). As in the Nespresso case (Pinto et al., 2017), this strategy deals with innovating the entire business model. The products are redesigned following a new value proposition derived from the new meaning to be offered to customers. In a cascade effect, the whole organization changes to seamlessly deliver the new meaning to customers.

(2) Product innovation of meaning: based on the traditional product innovation framework, innovation of meaning can be limited to the product. Apple iPhone is an exemplary case in that it detached from the current competition, focussing on bringing a radical new meaning to an existing product category (Verganti, 2017). The existing meaning of the product (i.e. "connecting people" or "my office in my pocket") was radically innovated ("my life in my pocket") without redesigning the meaning of the retail service (i.e. the Apple Store remains a place for trying out the new consumer electronics experience).

(3) Retail service innovation of meaning: the company starts from a powerful and still relevant meaning of the product, proposing a radical new meaning for the retail experience. IKEA maintained the meaning of the furniture product (i.e. democratic design), but over the decades redesigned the meaning of the retail experience (i.e. in the 1980s, the "do it yourself" experience; in the 1990s, the "learning experience"; in the 2000s, the "family destination store"; in the 2010s, "dynamic access for nomadic people").

This research focusses on the latter strategy. While many researchers focussed on the product innovation of meaning as independent from the service (Gasparin and Green, 2018; Dell'Era et al., 2011) and on the synergic orchestration of the two dimensions (Pinto et al., 2017; Battistella et al., 2012), no prior research has investigated the innovation of meaning from a retail service point of view, as detached from the products sold. However, this could be
Product and retail service meaning 
IJRDM

49,1

promising in that it may reinvigorate or sustain product category sales without allocating resources to innovating the product itself.

The next section shows the comparison between the two cases, Lush and The Body Shop, which compete in the same market, with the same product meaning, albeit with different meanings in their retail service.

\section{0}

\section{Methodology}

A case study methodology has been selected to analyse a phenomenon dealing with contemporary real life and over which researchers have no control (Yin, 2011). While case studies have been subject to criticism, mainly from positivism-led scholars (Yin, 2011), due to the limited generalizability of findings and the possible biases that researchers might introduce with their deductions, they are at the same time an effective tool to investigate social systems from different perspectives. Multiple entry data points were used to minimize those threats (Yin, 2011). A paired comparison method (Tarrow, 2010) was adopted to analyse and compare retailers of a similar scale and in the same industry. While the method presents some limitations in the possibility of making predictions based on the case studies, due to the impossibility of controlling all the relevant variables (Wynn and Williams, 2012), it is particularly appropriate to explain a phenomenon and to open new avenues for research by means of exploratory research (Yin, 2011). Further quantitative research could build on this study's findings to propose and generalize new theories.

The cases were selected according to two criteria: (1) innovative product companies that own directly operated stores based on the last five years' rankings and awards (Interbrand, Ebeltoft, Deloitte, Accenture); (2) to ensure comparability, the degree of internationalization, the size of the business, the closeness of the proposed new meanings, the presence of proprietary products in the retail spaces and their location in large Italian cities. The case selection proceeded over different steps. The first consisted of an extensive analysis of secondary sources, mainly conducted by the two authors, focussed on the following:

(1) Institutional websites: mainly to gather information on the value proposition to the market, the brand values, company description and characteristics, initiatives and product-service lines.

(2) Third-party websites: to access public financial data, company characteristics, articles on the topic of innovation and interviews with company managers.

(3) Academic papers: to review existing peer-reviewed knowledge related to the two selected retailers.

This first step of the analysis allowed the researchers to validate their initial perceptions of the two case studies, confirming the comparable dimensions and the different innovation outcomes according to very similar strategic choices.

The key characteristics related to the innovation of meaning envisioned by the two companies were validated and confirmed as the same by a panel consisting of four domain experts, two directly involved in the innovation field, the main investigation of this study, one with a background in economics and one with a background in semiotics. The second round consisted of ethnographic research in the two selected retailers (LeCompte and Schensul, 2010). The objective was twofold: on one side, confirming the preliminary findings gathered through the secondary source analysis; on the other, it allowed us to gather more detailed insights based on the observation of customers and front-line staff in the context of the shopping experience. The method was selected based on the high culture-related topic under investigation and the possibility to generate relevant findings without directly influencing the system under study. The strengths in this type of analysis rely on the different 
perspectives of researchers when investigating the phenomenon, enriching the set of insights. Visits were carried out in the two locations of the two retail stores in Milan.

As a result of the additional knowledge gathered, the two cases were analysed by adapting the servuction model (Eiglier and Langeard, 1975; Grönroos, 2012) to the innovation of meaning framework. As in previous studies (e.g. Pinto et al., 2017), its reinterpretation in light of IOM allows researchers to draw conclusions about the relationship between the meaning provided and the experience lived by customers. The synthesis through the servuction model was then subjected to the last validation step before constructing the definitive findings and recommendations. The framework, illustrated in Table 1 , links the three main retail innovation dimensions: technology (HOW), market (WHAT) and meaning (WHY), as described in Pinto et al. (2017).

\section{Empirical setting}

The choice of focussing on the beauty industry was not casual. Indeed, beauty has always been one of the biggest sectors for aggregate retail sales, and beauty and personal care retailers keep growing year by year (Danziger, 2019). Moreover, the industry players have been heavily concerned with a dominant meaning that emerged in the last decades and called each player to action: sustainability (Whelan and Konthral-Sacco, 2019). Although the theme has become important in each aspect of modern society, special emphasis can be found in the beauty and personal care sector. The reason is twofold: people are increasingly aware of the products they use to care for their body; the beauty industry produces large quantities of plastic waste due to the extensive use of packaging (Baird-Murray, 2018). For these reasons, Lush and The Body Shop are two critical cases in investigating the meaning of sustainability in the beauty industry.

The Body Shop, founded in 1976, is acknowledged as the precursor of the movement towards natural beauty product supply. Anita Roddick, the founder, wanted to produce and sell products that were not only sustainable but also ethical and natural. Starting out in the United Kingdom, the company's growth quickly accelerated, leading to a rapid expansion in Europe and to listing on the London Stock Exchange. Given the perfect timing in addressing an increasingly significant meaning in society (Verganti, 2009), the brand's value grew at an incredible pace.

In 1995, almost two decades later, Lush was founded by two professionals already operating in the beauty industry who were committed to producing products only following natural recipes and no animal testing. Interestingly, Lush was not born as a retail company, but as a supplier of The Body Shop. Following a rather turbulent relationship and the opportunity of running a proprietary store, Lush, whose name was at that time "Cosmetics-to-Go", opened its first retail store in Poole selling fresh, handmade products, taking advantage of the boom in attention towards sustainable and ethical values in society.

Although the nature of the two firms is quite similar, and they are connected in their birth, their retail spaces are designed in very different ways. The Body Shop is based on a clean,

\begin{tabular}{|c|c|c|}
\hline HOW & WHAT & WHY \\
\hline $\begin{array}{l}\text { New technological and } \\
\text { architectural solutions that enable } \\
\text { a more advanced or refined } \\
\text { interaction with the service from a } \\
\text { utilitarian perspective }\end{array}$ & $\begin{array}{l}\text { New technological and } \\
\text { environmental solutions that } \\
\text { enhance the customer experience } \\
\text { by modifying the hedonic } \\
\text { involvement and the creation of } \\
\text { memories }\end{array}$ & $\begin{array}{l}\text { New intangible values that are } \\
\text { delivered through the store } \\
\text { environment and service } \\
\text { activities that enable deeper } \\
\text { emotional, affective and cognitive } \\
\text { engagement }\end{array}$ \\
\hline
\end{tabular}

Product and retail service meaning 
IJRDM

49,1

white and green design of their stores, which communicate calm and relaxation. Lush, on the contrary, provides spaces where all the senses are stimulated at their maximum, which are completely not aligned with the average competitor in the category.

\section{Findings}

To facilitate the comprehension of findings, related to the comparison between the two cases, the results are presented organized on the basis of the two cases. Both are then summarized using the servuction model adapted to the IOM (Pinto et al., 2017).

\section{The Body Shop}

Being the first retailer in bringing a concept focussed on the meaning of sustainability to the market, The Body Shop was able to grow in revenues with up to approximately 3,000 stores operating all over the world. In 2006, it was acquired by the beauty giant L'Oréal. However, after some years of stable or slightly declining sales, $-4.8 \%$ in 2017 (according to the Economist), L'Oréal sold it to the Brazilian company Natura \& Co.

As a result of the acquisition by L'Oréal, the company had to combat some criticisms from its customers. In particular, some parts of the customer base were against the acquisition by a global giant that could undermine the traditional values. L'Oréal tried to maintain a strong brand identity, opening mono-brand stores and keeping its meaning at the centre of the customer experience. As a consequence, The Body Shop stores are now structured as shown in Table 2.

As regards the HOW dimension, the stores are designed as an aseptic place where the focus is on the products displayed without any distracting elements. The colours are light and pastel. A great deal of green is present to resemble sustainability along with a relevant presence of white, which recalls a professional and pure environment. The same is reflected in the scent, which is natural and delicate. Nothing in the store overwhelms the senses, providing a natural feeling. The sales assistants are knowledgeable and provide people with information about the products. As in a pharmacy, the advice provided is tailored and professional, aimed at suggesting the perfect product to obtain a specific result. The packaging is professional too, the product names explain the function and information on ingredients and preparation is provided. As is typical of beauty retailers, customers can test products on their skin using traditional testers, with fountains for washing that resemble a natural setting. These features reflect a WHAT dimension centred on knowledge gathering and product testing. The experience lived by customers revolves around the possibility of testing the products, along with relevant information that the sales assistants provide. As for the WHY, the meaning that The Body Shop aims at transferring is centred on the concept of social and environmental sustainability. By providing such an experience, people enter the stores to achieve responsible consumption by acquiring knowledge and purchasing responsible products.

Table 2.

Solutions, experiences and meaning offered by The Body Shop

\begin{tabular}{llc}
\hline HOW (infrastructure) & WHAT (experience) & WHY (meaning) \\
\hline $\begin{array}{l}\text { Informative packaging } \\
\text { Sales assistants teach the origins of their products }\end{array}$ & Getting knowledge & Responsible consumption \\
$\begin{array}{l}\text { Professional lighting } \\
\begin{array}{l}\text { Fountains to wash your hands } \\
\text { Product trials }\end{array}\end{array}$ & \\
\end{tabular}


Lush

According to the company's vision, Lush's values are based on transparency, sustainability (both social and environmental), freshness and naturalness. To sustain these values, the company does not intensively leverage traditional marketing, instead showcasing responsible behaviour. Creating products with this meaning, Lush was able to penetrate the natural beauty products market with nearly 1,000 stores all over the world at the end of 2017 and a continuing expansion rate accounting for $+26 \%$ of worldwide sales in the same year (Loeb, 2017).

This meaning is highly evident in their communications. A first dimension is related to the brand name, which was chosen after a contest proposed to customers and following the smooth, fresh pronunciation of the word Lush itself. The company logo is very simple, mainly giving space to the name, with no additional cues apart from a clarification of the "Fresh Handmade Cosmetics" offering.

However, the products do not follow the same logic of recalling sustainability through the intense use of green and light colours. Instead, entering a Lush store is a full multi-sensory experience, where products are at the centre, and people cannot avoid coming into contact with them. Table 3 shows the main characteristics of the Lush retail service, focussing on the HOW dimension.

What everyone who enters a Lush store remembers is the smell. Even if people just pass by without entering the store, they are enveloped by a very strong fragrance. The scent is so strong that it can be smelled from quite far away, completely in contrast with the delicate perfumes traditionally used for fresh and sustainable products. The store entrance has another peculiar characteristic: instead of the universal warm and smiley welcome, sales assistants receive customers by either playing with products, as in a circus, or through physical contact to make them try the products. This playful feeling is also sustained by the space design and the product displays. Rather than some aseptic shelves, highlighting products to underline their importance and quality, Lush stores are organized as bazaars. Dark wood predominates in the shelving, walls are often black and heavy lighting illuminates the spaces. The products resemble toys for children, are very colourful and sometimes shaped like something else (i.e. the rocket soap, Figure 2). The playful names on the packaging contribute to this feeling. Finally, products can be tested and a very simple sink is provided for this purpose.

As regards the WHAT dimension, the experience lived by customers derives directly from the described characteristics. People who enter Lush stores share the same feelings: excitement and happiness. The overload of stimuli makes them feel that the place is different from others, providing a form of entertainment. Not only a place for buying sustainable and responsible products but also to have fun. People learn from the product labels that are explained by sales employees while they joke with each other. As summarized in Table 3 , the kind of experience that can be lived in Lush stores is distant from the usual experience in traditional, natural and responsible stores. The Lush retail service aims at offering people
Product and retail service meaning

\begin{tabular}{lrr}
\hline HOW (infrastructure) & WHAT (experience) & WHY (meaning) \\
\hline $\begin{array}{l}\text { Heavy smell } \\
\text { Sales assistants play and make shows with products }\end{array}$ & Play with products & Playful awareness \\
$\begin{array}{l}\text { Displays simulate unrelated contexts (e.g. aperitivo table) } \\
\text { Bazaar-line product display }\end{array}$ & Learn with joy & Solutions, experiences \\
$\begin{array}{l}\text { Funny names which explain products' use } \\
\text { Posters full of that explain sustainability to everyone }\end{array}$ & \\
and meaning offered \\
by Lush
\end{tabular}




\section{IJRDM 49,1}

Figure 2.

The "rocket soap" by Lush

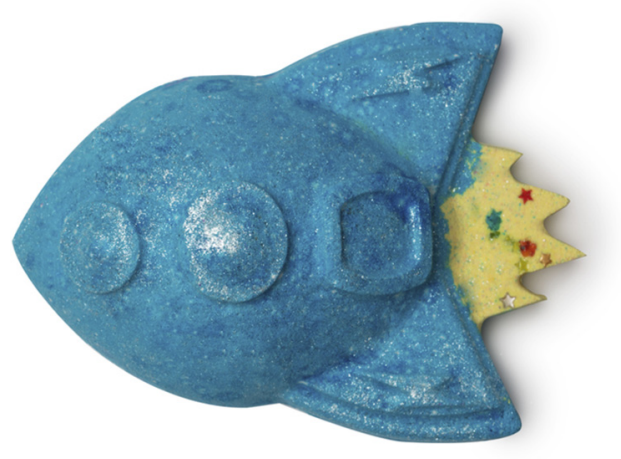

playful awareness, where the sustainability of products is expressed through the playfulness of the service.

The HOW and WHAT dimensions directly express the meaning behind the WHY dimension (Verganti, 2017). While the meanings of products are still based on the initial values the two companies proposed, there is a profound difference in their retail service design.

\section{Discussion}

Both Lush and The Body Shop came to the market offering the same product IOM centred on the concept of social and environmental sustainability. The two firms compete in the same market with similarly priced products and comparable store diffusion and location.

However, the two retail services are very different in the experience they provide to customers. The Body Shop stores are built around the concept of social and environmental sustainability, a professional environment, proposing the "responsible consumption" meaning (Table 2). Lush, on the other hand, has proposed a new way of experiencing their sustainable and beauty-related products. Although providing products with the same meaning, the retail service is built on "playful awareness", traditional values mixed with a modern and childish tendency to play and to gamify the experience. Table 4 shows that while the missions and product meanings of both companies remain the same, the way these are conveyed through the retail service meaning is very different.

This is also reflected in the experiences lived by customers, which are definitely different. In line with Schmitt (1999), the experience is constituted of sensorial as well as cognitive elements. In Lush, the sensorial elements are exaggerated: perfume can be smelled from metres outside the store, the product colours, forms and the shelves capture attention inside.

\begin{tabular}{llll}
\hline Company & Mission & Products' meaning & Retail's meaning \\
\hline $\begin{array}{l}\text { The Body } \\
\text { Shop }\end{array}$ & $\begin{array}{l}\text { We search the world for the finest ethically } \\
\text { sourced ingredients to create a range of naturally } \\
\text { inspired beauty products }\end{array}$ & $\begin{array}{l}\text { A responsible and } \\
\text { natural product }\end{array}$ & $\begin{array}{l}\text { Responsible } \\
\text { consumption }\end{array}$ \\
$\begin{array}{l}\text { Le make our products by hand with only } \\
\text { vegetarian ingredients and little-to-no } \\
\text { preservatives }\end{array}$ & $\begin{array}{l}\text { A responsible and } \\
\text { natural product }\end{array}$ & $\begin{array}{l}\text { Playful } \\
\text { awareness }\end{array}$ \\
& & &
\end{tabular}

Table 4.

Mission, products' meaning and retail meaning, The Body Shop vs Lush 
The touchpoints and the sales assistants' behaviours aim at attracting customers in a fun mood of playing. At the same time, as in The Body Shop stores, the same cognitive dimension is transferred to customers. Products and packaging, as well as additional material, are aimed at conveying information about the company's commitment to social and environmental sustainably. However, the information in Lush stores is not straightforward and tends to be gamified by the retailer where the store layout and the environment recall a childish and playful meaning. The data gathered and their analysis allow this paper to answer the research question: How do companies manage the relationship between product and retail service meaning?

As our case studies show, the two meanings may be separate. Intuitively, providing the same meaning through both the products and the retail services is a way to organize the stores. However, as Lush shows, the two meanings may also differ.

While IOM aims at addressing the "reason why" consumers buy a product or service (Verganti, 2009, 2017), such reason also evolves. As is typical for setting business standards, competitors are likely to imitate the conceived meaning when it becomes dominant in the industry. At a certain point, the envisioned meaning can become outdated through the evolution of societal beliefs and new values (Latour and Woolgar, 2013). This is what occurred with sustainability in the cases under study. In the years of The Body Shop's foundation (1970s), sustainability was an emergent issue and meaning for society (Whelan and Kronthal-Sacco, 2019). Over the following decades, people increasingly paid attention to the environmental issue, raising its importance not only in the beauty sector but in the whole spectrum of social activities. Sustainability has now become a major concern for people and a must-have for any business to stay in the market, at least in Western economies (Shadymanova et al., 2014). For this reason, meaning centred on sustainability alone risks being under-perceived, taken for granted and no longer differentiating the provider. Although sustainability may be articulated in very different ways (Stubbs and Cocklin, 2008), what builds customer perceptions often differs from what the company communicates, causing a flattening of the value perceived (Beltagui et al., 2015). The case of Lush shows that the retailer has been able to communicate the sustainability value, which is leveraged through informative material into the store and the way products are built, but has also been able to associate a novel image to the traditional beauty consumption. In this way, Lush has been able to communicate a new meaning, that of playful and fun consumption, without changing its core and still visible meaning, sustainability. In doing so, they paid careful attention in designing their stores around the novel and differentiating meaning, which is immediately visible to all the visitors.

Thus, providing a store experience that has a different meaning than the products may be a viable strategy to keep a company's offering up to date. In fact, as Gasparin and Green (2018) say, product meanings can evolve as a consequence of social micro-processes of negotiation between the provider and the receiver, by offering a new service meaning, companies may manage this evolution and keep aligned with the new customers' aspirations. Lush's products still embody the original sustainability meaning, but their way of being sold allows the company to differentiate from competitors. At the same time, it allows bringing a fresh new meaning to the market while still embodying the traditional "must-have" values (Kano, 1984).

\section{Conclusions and implications}

The application of the IOM framework in the retail context creates some opportunities that are driven by the peculiar relationship between the products sold and the retail service. This study highlights an innovation strategy that does not imply reconceiving the product itself. Retailers can provide different meanings between the products they sell and the retail
Product and retail service meaning 
IJRDM

49,1

services used to sell those products. Thus, the IOM does not necessarily imply a redefinition of the entire business, but can be limited to a part of it. In this way, companies can communicate a new meaning to customers that does not substitute the old one, the two different meanings accumulate and contribute in creating a differentiating experience. This is especially critical in those cases, such as sustainability, where the current meaning is still not outdated, but simply taken for granted. Changing the store meaning allows the company to continue offering the same values, which are still asked by the customers, in a customer experience that is perceived as more novel and differentiating in respect to competitors. Importantly, the new retail meaning cannot be in contrast with the product meaning to benefit from possible synergies and avoid a negative perception of the overall offer.

This research is important for both theory and practice. On an academic side, it sheds light on a phenomenon that has been previously neglected in the IOM framework: decoupling the product meaning from the retail service meaning. In addition to that, the research aims to provide managers with a viable strategic option to sustain products sales when its embodied meaning has become dominant and diffused in the market. Changing the retail service meaning allows offering an experience based on both the meanings embodied in the products and the service, potentially creating competitive advantage. This can be leveraged to revive a mature or declining product meaning, albeit paying close attention to how and when to do so for optimum effect.

While shedding light on a relevant and neglected phenomenon, this research also entails some limitations to be taken into account. Characterizing as a first exploratory study, it relies on a qualitative methodology, which doesn't allow to generalize findings. Being rooted into the flourishing beauty context, authors recommend to transfer the findings to contexts characterized by similar growth patterns, while more research on the possibility of innovating the stores' meaning in a declining industry must be carried out in the future. Moreover, this first exploratory study describes and brings a new phenomenon to visibility. We expect further research to identify relationships among variables and a broader understanding of all the influencing and mediating factors in the context. Quantitative methodologies, as experiments and difference in difference analyses, would help in further detailing the phenomenon and going towards a theory of the innovation of meaning implementation in retail services.

Building on these considerations, the authors suggest two main directions to continue on the same research avenue. First, future studies need to investigate the phenomenon in different retail sectors, by looking at multiple cases to take into account the different specificities that characterize each empirical setting. Second, researchers need to employ quantitative methodologies by isolating relevant variables and testing new assumptions related to the provision of two different meanings. The timing to introduce an innovation in a service's meaning, the relationship the new meaning needs to have with the products' one and the contextual factors that may influence a positive outcome need to be assessed. Last, those new assumptions must be tested and connected into a model which would be used to make predictions.

\section{References}

Abernathy, W.J. and Clark, K.B. (1985), "Innovation: mapping the winds of creative destruction", Research Policy, Vol. 14 No. 1, pp. 3-22.

Argyres, N., Bigelow, L. and Nickerson, J.A. (2015), "Dominant designs, innovation shocks, and the follower's dilemma”, Strategic Management Journal, Vol. 36 No. 2, pp. 216-234.

Artusi, F. and Bellini, E. (2020), "Design and the customer experience: the challenge of embodying new meaning in a new service", Creativity and Innovation Management, pp. 1-10, doi: 10.1111/ caim.12364. 
Artusi, F., Bellini, E., Dell'Era, C. and Verganti, R. (2020), "Designing an omni-experience to save retailing: lessons from an Italian book retailer", Research-Technology Management, Vol. 63 No. 3, pp. 24-32.

Baird-Murray, K. (2018), "Waste not: the future of sustainability in the beauty industry", Vogue, available at: https://www.vogue.co.uk/gallery/sustainability-in-the-beauty-industry (accessed 14 November 2019).

Battistella, C., Biotto, G. and De Toni, A.F. (2012), "From design driven innovation to meaning strategy", Management Decision, Vol. 50 No. 4, pp. 718-743.

Baxter, M. (2018), Product Design, CRC Press, London.

Beck, N. and Rygl, D. (2015), "Categorization of multiple channel retailing in multi-, cross-, and omnichannel retailing for retailers and retailing", Journal of Retailing and Consumer Services, Vol. 27, pp. 170-178.

Bell, D.R., Gallino, S. and Moreno, A. (2017), "Offline showrooms in omnichannel retail: demand and operational benefits”, Management Science, Vol. 64 No. 4, pp. 1629-1651.

Bellis, P. and Verganti, R. (2019), "Pairs in innovation: how working in pairs helps organisations to move into a new shared direction", International Journal of Innovation Management, Vol. 24 No. 03, 2050072.

Beltagui, A., Darler, W. and Candi, M. (2015), "Measuring the deliverable and impressible dimensions of service experience", Creativity and Innovation Management, Vol. 24 No. 3, pp. 478-492.

Byun, J., Sung, T. and Park, H. (2018), "Technological innovation strategy: how do technology life cycles change by technological area”, Technology Analysis and Strategic Management, Vol. 30 No. 1, pp. 98-112.

Chiang, W.K., Chhajed, D. and Hess, J.D. (2003), "Direct marketing, indirect profits: a strategic analysis of dual-channel supply-chain design”, Management Science, Vol. 49 No. 1, pp. 1-20.

Childers, T.L., Carr, C.L., Peck, J. and Carson, S. (2001), "Hedonic and utilitarian motivations for online retail shopping behavior", Journal of Retailing, Vol. 77 No. 4, pp. 511-535.

Choi, B. and Choi, B. (2014), "The effects of perceived service recovery justice on customer affection, loyalty, and word-of-mouth", European Journal of Marketing, Vol. 48 Nos 1/2, pp. 108-131.

Danzinger, P. (2019), " 6 trends shaping the future of the $\$ 532 \mathrm{~B}$ beauty business", Forbes, 1 September available at: https://www.forbes.com/sites/pamdanziger/2019/09/01/6-trends-shaping-the-futureof-the-532b-beauty-business/\#4fdaa3c0588d (accessed 1 May 2020).

Dell'Era, C., Buganza, T., Fecchio, C. and Verganti, R. (2011), "Language brokering: stimulating creativity during the concept development phase", Creativity and Innovation Management, Vol. 20 No. 1, pp. 36-48.

Edvardsson, A., Enquist, B. and Hay, M. (2006), "Values-based service brands: narratives from IKEA", Managing Service Quality: An International Journal, Vol. 16 No. 3, pp. 203-246.

Eiglier, P. and Langeard, E. (1975), "Une approche nouvelle pour le marketing des services”, Revue Francaise de Gestion, Vol. 2, pp. 97-144.

Eisenman, M. (2013), "Understanding aesthetic innovation in the context of technological evolution", Academy of Management Review, Vol. 38 No. 3, pp. 332-351.

Gasparin, M. and Green, W. (2018), "Reconstructing meaning without redesigning products: the case of the Serie7 chair", Creativity and Innovation Management, Vol. 27 No. 4, pp. 401-413.

Grönroos, C. (2012), "Conceptualising value co-creation: a journey to the 1970 s and back to the future", Journal of Marketing Management, Vol. 28 Nos 13-14, pp. 1520-1534.

Hagberg, J., Sundstrom, M. and Egels-Zandén, N. (2016), "The digitalization of retailing: an exploratory framework", International Journal of Retail and Distribution Management, Vol. 44 No. 7, pp. 694-712.
Product and retail service meaning 
IJRDM

49,1

Hall, A. and Towers, N. (2017), "Understanding how millennial shoppers decide what to buy: digitally connected unseen journeys", International Journal of Retail and Distribution Management, Vol. 45 No. 5, pp. 498-517.

Hamel, G. and Prahalad, C.K. (1992), “Capabilities-based competition”, Harvard Business Review, Vol. 70 No. 3, pp. 164-170.

Huang, Y. and Huddleston, P. (2009), "Retailer premium own-brands: creating customer loyalty through own-brand products advantage", International Journal of Retail and Distribution Management, Vol. 37 No. 11, pp. 975-992.

Jahnke, M. (2012), "Revisiting design as a hermeneutic practice: an investigation of Paul Ricoeur's critical hermeneutics", Design Issues, Vol. 28 No. 2, pp. 30-40.

Jocevski, M., Arvidsson, N., Miragliotta, G., Ghezzi, A. and Mangiaracina, R. (2019), "Transitions towards omni-channel retailing strategies: a business model perspective", International Journal of Retail and Distribution Management, Vol. 47 No. 2, pp. 78-93.

Kano, N. (1984), "Attractive quality and must-be quality", Hinshitsu (Quality, The Journal of Japanese Society for Quality Control), Vol. 14, pp. 39-48.

Knudsen, L.S. and Haase, L.M. (2019), "The construction of meaning in design-driven projects: a paradox initiated process", International Journal of Design Creativity and Innovation, Vol. 7 No. 3, pp. 129-143.

Kranzbühler, A., Kleijnen, M.H., Morgan, R.E. and Teerling, M. (2018), "The multilevel nature of customer experience research: an integrative review and research agenda", International Journal of Management Reviews, Vol. 20 No. 2, pp. 433-456.

Krippendorff, K. and Butter, R. (2008), "Semantics: meanings and contexts of artifacts", in Schifferstein, H.N.J. and Hekkert, P. (Eds), Product Experience, Elsevier, New York, NY.

Laing, A. and Royle, J. (2013), "Examining chain bookshops in the context of 'third place", International Journal of Retail and Distribution Management, Vol. 41 No. 1, pp. 27-44.

Latour, B. and Woolgar, S. (2013), Laboratory Life: The Construction of Scientific Facts, Princeton University Press, Princeton, New Jersey.

LeCompte, M.D. and Schensul, J.J. (2010), Designing and Conducting Ethnographic Research: An Introduction, Altamira Press, Lanham.

Loeb, W. (2017), "Lush beauty: taking the industry by storm thanks to young love", Forbes, available at: https://www.forbes.com/sites/walterloeb/2017/04/07/lush-beauty-taking-theindustry-by-storm-thanks-to-young-love/\#76ed6e9311c5 (accessed 18 November 2019).

Loupiac, P. and Goudey, A. (2020), "How website browsing impacts expectations of store features", International Journal of Retail and Distribution Management, Vol. 48 No. 1, pp. 92-108.

Lovelock, C. and Gummesson, E. (2004), "Whither services marketing? In search of a new paradigm and fresh perspectives", Journal of Service Research, Vol. 7 No. 1, pp. 20-41.

Lyytinen, K., Yoo, Y. and Boland, R.J. Jr (2016), "Digital product innovation within four classes of innovation networks", Information Systems Journal, Vol. 26 No. 1, pp. 47-75.

Magistretti, S., Dell'Era, C. and Verganti, R. (2020a), "Look for new opportunities in existing technologies: leveraging temporal and spatial dimensions to power discovery", ResearchTechnology Management, Vol. 63 No. 1, pp. 39-48.

Magistretti, S., Dell'Era, C. and Verganti, R. (2020b), "Searching for the right application: a technology development review and research agenda", Technological Forecasting and Social Change, Vol. 151, 119879.

Meyer, C. and Schwager, A. (2007), "Understanding customer experience", Harvard Business Review, Vol. 85 No. 2, pp. 116-126.

Pantano, E. and Gandini, A. (2018), "Shopping as a 'networked experience': an emerging framework in the retail industry", International Journal of Retail and Distribution Management, Vol. 46 No. 7 , pp. 690-704. 
Pantano, E. and Viassone, M. (2015), "Engaging consumers on new integrated multichannel retail settings: challenges for retailers", Journal of Retailing and Consumer Services, Vol. 25, pp. 106-114.

Pine, B.J. and Gilmore, J.H. (1998), "Welcome to the experience economy", Harvard Business Review, Vol. 76, pp. 97-105.

Pinto, G.L., Dell'Era, C., Verganti, R. and Bellini, E. (2017), "Innovation strategies in retail services: solutions, experiences and meanings", European Journal of Innovation Management, Vol. 20 No. 2, pp. 190-209.

Porter, M.E. (1996), "What is strategy”, in Mazzucato, M. (Ed.), Strategy for Business: A Reader, Sage, London.

Rosner, D. and Bean, J. (2009), "Learning from IKEA hacking: I'm not one to decoupage a tabletop and call it a day", Proceedings of the SIGCHI Conference on Human Factors in Computing Systems, ACM, p. 419.

Roth, V.J. and Klein, S. (1993), "A theory of retail change", International Review of Retail, Distribution and Consumer Research, Vol. 3 No. 2, pp. 167-183.

Sanasi, S., Artusi, F., Ghezzi, A. and Bellini, E. (2019), "Filtering and enabling meaning perception: a business model perspective", Paper presented at ISPIM Conference, 16-19 June, Florence.

Schmitt, B. (1999), "Experiential marketing”, Journal of Marketing Management, Vol. 15 Nos 1-3, pp. $53-67$.

Shadymanova, J., Wahlen, S. and van der Horst, H. (2014), "Nobody cares about the environment': Kyrgyz' perspectives on enhancing environmental sustainable consumption practices when facing limited sustainability awareness", International Journal of Consumer Studies, Vol. 38 No. 6, pp. 678-683.

Söderlund, M. (1998), "Customer satisfaction and its consequences on customer behaviour revisited: the impact of different levels of satisfaction on word-of-mouth, feedback to the supplier and loyalty", International Journal of Service Industry Management, Vol. 9 No. 2, pp. 169-188.

Stubbs, W. and Cocklin, C. (2008), "Conceptualizing a sustainability business model", Organization and Environment, Vol. 21 No. 2, pp. 103-127.

Takeyama, M., Tsukui, K., Yamaguchi, H. and Matsuo, K. (2016), "Design-driven service innovation: a method to change the meaning of a service", Service Design Geographies. Proceedings of the ServDes. 2016.

Tarrow, S. (2010), "The strategy of paired comparison: toward a theory of practice", Comparative Political Studies, Vol. 43 No. 2, pp. 230-259.

Teece, D.J., Pisano, G. and Shuen, A. (1997), "Dynamic capabilities and strategic management", Strategic Management Journal, Vol. 18 No. 7, pp. 509-533.

Toivonen, M. and Tuominen, T. (2009), "Emergence of innovations in services", The Service Industries Journal, Vol. 29 No. 7, pp. 887-902.

Trabucchi, D., Pellizzoni, E., Buganza, T. and Verganti, R. (2017), "Interplay between technology and meaning: how music majors reacted?", Creativity and Innovation Management, Vol. 26 No. 4, pp. 327-338.

Utterback, J., Vedin, B.A., Alvarez, E., Ekman, S., Walsch, S., Tether, B. and Verganti, R. (2006), Design Inspired Innovation, World Scientific, Boston.

Verganti, R. (2009), Design Driven Innovation: Changing the Rules of Competition by Radically Innovating what Things Mean, Harvard Business Press, Harvard.

Verganti, R. (2017), Overcrowded: Designing Meaningful Products in a World Awash with Ideas, MIT Press, Boston.

Verhoef, P.C., Lemon, K.N., Parasuraman, A., Roggeveen, A., Tsiros, M. and Schlesinger, L.A. (2009), "Customer experience creation: determinants, dynamics and management strategies", Journal of Retailing, Vol. 85 No. 1, pp. 31-41.
Product and retail service meaning 
IJRDM

49,1

Verhoef, P.C., Kannan, P.K. and Inman, J.J. (2015), "From multi-channel retailing to omni-channel retailing: introduction to the special issue on multi-channel retailing", Journal of Retailing, Vol. 91 No. 2, pp. 174-181.

Visnjic, I., Wiengarten, F. and Neely, A. (2016), "Only the brave: product innovation, service business model innovation, and their impact on performance", Journal of Product Innovation Management, Vol. 33 No. 1, pp. 36-52.

Whelan, T. and Kronthal-Sacco, R. (2019), "Research: actually, customers do buy sustainable products", Harvard Business Review, 19 June, available at: https://hbr.org/2019/06/researchactually-consumers-do-buy-sustainable-products (accessed 2 May 2020).

Wynn, D. Jr and Williams, C.K. (2012), "Principles for conducting critical realist case study research in information systems", MIS Quarterly, pp. 787-810.

Yin, R.K. (2011), Applications of Case Study Research, Sage, London.

\section{About the authors}

Federico Artusi is a PhD student at the School of Management of Politecnico di Milano. He is also a senior researcher in the Observatory for Digital Innovation in Retail and in LEADIN'Lab, the Laboratory of LEAdership, Design and INnovation. His main research areas are Innovation, Design and New Service Development in the context of retail services. Federico Artusi is the corresponding author and can be contacted at: federico.artusi@polimi.it

Emilio Bellini is assistant professor at Politecnico di Milano, where he serves also as co-founder of LEADIN'Lab, the Laboratory of LEAdership, Design and INnovation in the School of Management, and scientific officer of the Observatory Digital Innovation in Retail. His research interest is in innovation management and organizational knowledge in new service development. On these topics he has published in journals such as International Journal of Innovation Management, International Journal of Knowledge Management Studies, International Journal of Information Systems and Change.

For instructions on how to order reprints of this article, please visit our website:

www.emeraldgrouppublishing.com/licensing/reprints.htm

Or contact us for further details: permissions@emeraldinsight.com 